\title{
Estimasi Sumber Daya Uranium Tipe Batupasir di Sektor Aloban, Sibolga, Tapanuli Tengah
}

\section{Uranium Resources Estimation of Sandstone-Type Deposit in Aloban Sector, Sibolga, Tapanuli Tengah}

\author{
Roni Cahya Ciputra*, Adi Gunawan Muhammad, Tyto Baskara Adimedha, \\ Heri Syaeful, I Gde Sukadana \\ Pusat Teknologi Bahan Galian Nuklir-BATAN \\ Jl. Lebak Bulus Raya No.9 Pasar Jumat, Jakarta, Indonesia, 12440 \\ *E-mail: roni.cahya@batan.go.id
}

Naskah diterima: 25 Maret 2019, direvisi: 27 Mei 2019, disetujui: 28 Mei 2019

DOI: $10.17146 /$ eksplorium.2019.40.1.5360

\begin{abstract}
ABSTRAK
Eksplorasi uranium di daerah Sibolga telah dilakukan sejak tahun 1978 oleh BATAN dan berhasil menemukan mineralisasi uranium tipe batupasir. Penelitian mengenai konsep mineralisasi uranium pada batupasir dan konglomerat di Sektor Aloban, Sibolga, telah dilakukan melalui data 22 titik bor yang menghasilkan penampang geologi, peta sebaran anomali, serta data cacahan radiometri dan geokimia. Penelitian ini bertujuan untuk mengetahui sumber daya uranium di Sektor Aloban dengan mencari hubungan antara nilai cacahan radiometri dan data geokimia pada data hasil penelitian sebelumnya menggunakan pendekatan geostatistik. Pengolahan geostatistik menggunakan perangkat lunak SGeMS menunjukkan nilai koefisien korelasi 0,5 sehingga data radiometri dan geokimia diinterpretasikan memiliki korelasi yang baik. Estimasi sumber daya uranium dihitung pada Satuan Konglomerat I dan Batupasir I yang memiliki sebaran lapisan mineralisasi tebal dan luas. Nilai kadar rata-rata uranium untuk Satuan Konglomerat I dan Satuan Batupasir I adalah 173,03 ppm U dan 161,54 ppm U secara berurutan. Estimasi sumber daya uranium di Sektor Aloban adalah 415 ton uranium sebagai sumber daya tereka.
\end{abstract}

Kata kunci: Sibolga, Aloban, uranium, sumber daya, tereka

\begin{abstract}
Uranium explorations in Sibolga Area have been conducted since 1978 by BATAN and successfully result in sandstone-type uranium mineralization. Research related to uranium mineralization concept on sandstone and conglomerate at Aloban Sector, Sibolga has been conducted through 22 boreholes data which resulted in the geological section, anomaly distribution along with radiometry counting and geochemistry data. This research objective is to obtain uranium resources in Aloban Sector by correlating radiometry counting and geochemical data from previous research by using a geostatistic approach. Geostatistical processing using SGeMS software shows a correlation coefficient of 0.5 so that the radiometry and geochemical data are interpreted to have a good correlation. Uranium Resources estimation was measured on Conglomerate I and Sandstone I units which are considered to have thick and wide mineralization distribution. The average uranium grade for Conglomerate I and Sandstone I units are 173.05 ppm $U$ and 161.54 ppm U respectively. Uranium resource estimation at Aloban Sector is 415 tons as inferred resources.
\end{abstract}

Keywords: Sibolga, Aloban, uranium, resources, inferred 


\section{PENDAHULUAN}

Badan Tenaga Nuklir Nasional (BATAN) telah melaksanakan eksplorasi sumber daya uranium di Sibolga, Sumatra Utara sejak tahun 1978 [1]. Sibolga merupakan suatu cekungan sedimentasi sehingga memiliki peluang pembentukan mineralisasi uranium tipe sedimenter. Eksplorasi yang semakin detail terus difokuskan pada batuan sedimen dengan harapan teknologi pengolahan uranium menggunakan metode insitu leaching dapat diterapkan pada batuan sedimen di Sibolga. Penerapan metode tersebut berdasarkan pertimbangan bahwa kapasitas produksi lebih fleksibel dan biaya pembangunan tambang menjadi lebih sedikit [2].

Berdasarkan penelitian sebelumnya, mineralisasi uranium di Sektor Aloban telah diklasifikasikan sebagai tipe endapan batupasir dengan subtipe epigenetik tabular [3]. Secara global, tipe endapan batupasir merupakan tipe endapan yang paling banyak ditemukan dibandingkan tipe endapan yang lain serta memiliki sumber daya paling besar keempat $[4,5]$ seperti terlihat pada Gambar 1 dan Gambar 2. Meskipun tipe endapan fosfat, black shale, dan lignit memiliki sumber daya terbesar, tipe tersebut dinilai kurang ekonomis dibandingkan dengan tipe endapan lainnya.

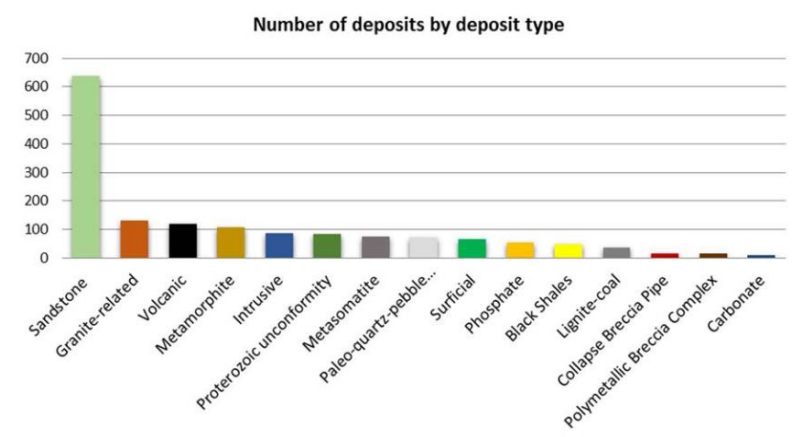

Gambar 1. Perbandingan jumlah endapan uranium menurut tipenya secara global [5].

Uranium pada tipe endapan batupasir dapat terendapkan pada kondisi reduksi akibat agen reduksi pada batuan seperti material karbonan, sulfida, hidrokarbon, dan mineral feromagnesian [4]. Penelitian pada 22 titik bor di Sektor Aloban menunjukkan bahwa material organik dapat terbentuk bersamaan dengan terbentuknya batuan pembawa uranium [6]. Uranium yang terlarut dalam air tanah sebagai akibat dari pelarutan batuan dan pelapukan batuan granitik kemudian terserap oleh material organik tersebut dan membentuk mineral uraninit, karnonit, dan kofinit.

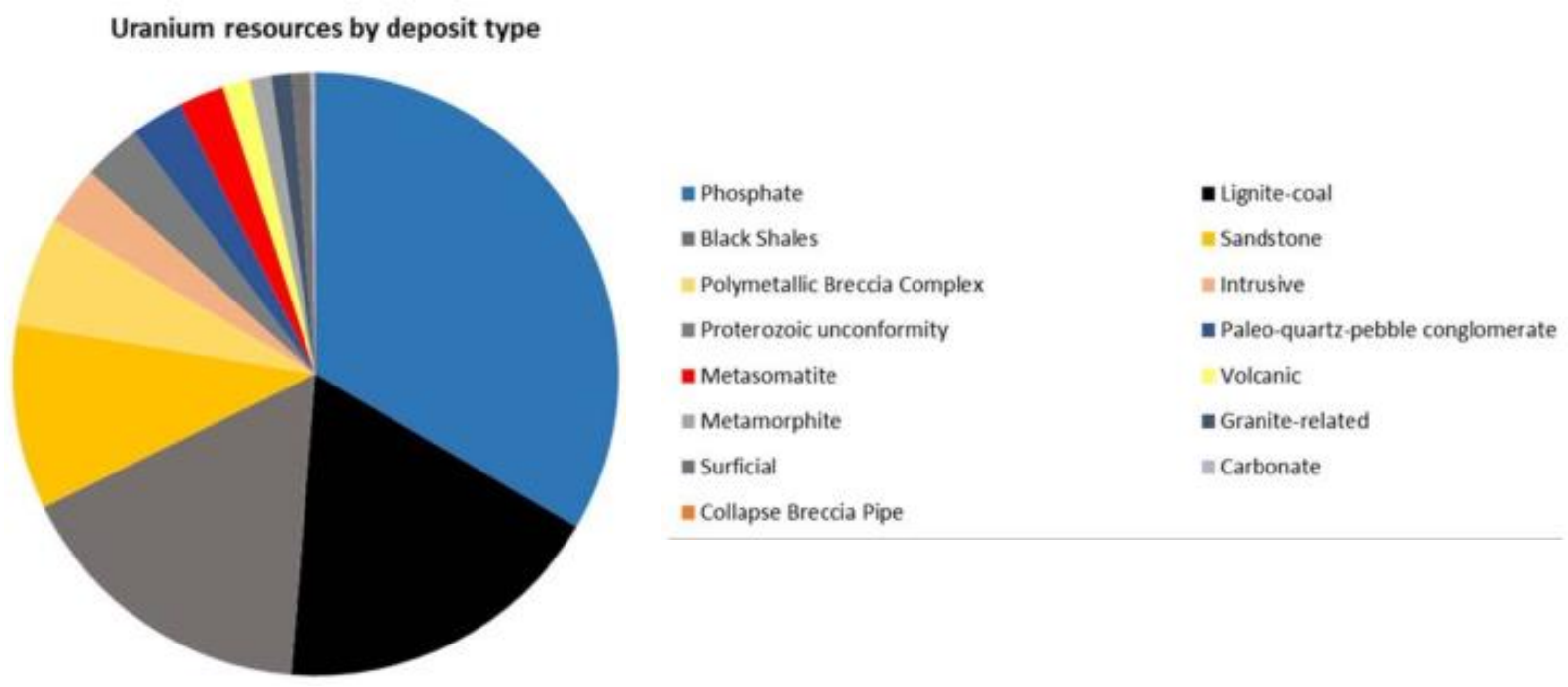

Gambar 2. Perbandingan sumber daya uranium menurut tipe endapan secara global [5]. 
Penelitian BATAN sebelumnya telah menghasilkan beberapa penampang geologi dan peta sebaran anomali beserta kadar berdasarkan data bor, namun data tersebut belum diaplikasikan lebih lanjut untuk menghitung sumber daya uranium yang ada. Penelitian ini bertujuan untuk mengetahui sumber daya uranium di Sektor Aloban dengan mencari hubungan antara nilai cacahan radiometri dan data geokimia menggunakan pendekatan geostatistik. Estimasi sumber daya uranium Sektor Aloban menggunakan penampang dan data-data lain yang telah dihasilkan pada penelitian sebelumnya.

\section{TATA KERJA}

Dalam rangka memperoleh angka estimasi sumber daya uranium di Sektor Aloban, dilakukan beberapa tahap kegiatan yang diawali dengan kajian data geologi dan mineralisasi uranium baik permukaan maupun bawah permukaan (pengeboran eksplorasi) serta kajian hasil penelitian terdahulu. Berdasarkan hasil kajian tersebut maka dilakukan pengolahan data pada penampang geologi dan sebaran mineralisasi untuk memperoleh parameter estimasi. Selanjutnya untuk mendapatkan angka estimasi kadar, dilakukan konversi dengan pendekatan geostatistik perbandingan cacahan radiometri dalam count per second (cps) yang terbaca dari data logging geofisika dengan data geokimia menggunakan perangkat lunak SGeMS. Setelah semua faktor yang diperlukan dalam estimasi terpenuhi, dilakukan estimasi sumber daya. Bagan tata kerja dapat dilihat pada Gambar 3.

\section{GEOLOGI DAERAH PENELITIAN}

Secara regional, daerah Sibolga tersusun atas 6 formasi batuan yaitu, dari tua ke muda, Formasi Kluet (metaarenit dan argilik) dan
Kompleks Sibolga (granit, diorit, dan granodiorit) berumur Perem, Formasi Barus (batupasir karbonan dan batubara) berumur Miosen Awal-Tengah, Tuf Toba, Aluvium Tua, dan Aluvium berumur Kuarter [7] (Gambar 4). Granit Kompleks Sibolga secara geokimia berasal dari larutan magmatik tinggi potasium (K) hingga ultrapotassik dan termasuk jenis granitoid busur kepulauan yang pembentukannya terkait sistem tektonik busur Sumatra [8]. Pembentukan granitoid busur kepulauan ini disertai dengan pembentukan granit intra-benua sebagai hasil gaya ekstensi saat tumbukan antara Blok Malaya Timur dengan Blok Sibumasu pada Trias Akhir hingga tumbukan Blok Sibumasu dengan Woyla Nappe pada Kapur Awal [9$11]$.

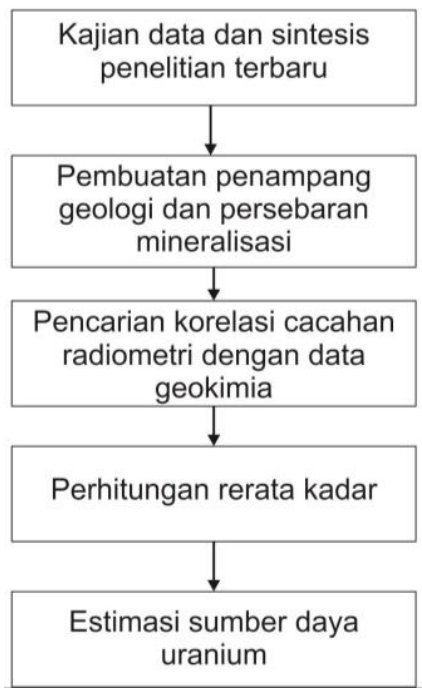

Gambar 3. Bagan tata kerja penelitian.

Secara lebih rinci, Sektor Aloban yang merupakan Kompleks Sibolga, terdiri atas 6 satuan batuan yaitu, Satuan Granit/ Granodiorit (G/Gd), Satuan Konglomerat 1 (KGL1), Satuan Batupasir 1 (BPS1), Satuan Konglomerat 2 (KGL2), Satuan Batupasir 2 (BPS2), dan Satuan Endapan Aluvium (Al) [6]. Sebaran litologi dari satuan batuan tersebut dapat dilihat pada Gambar 5. 


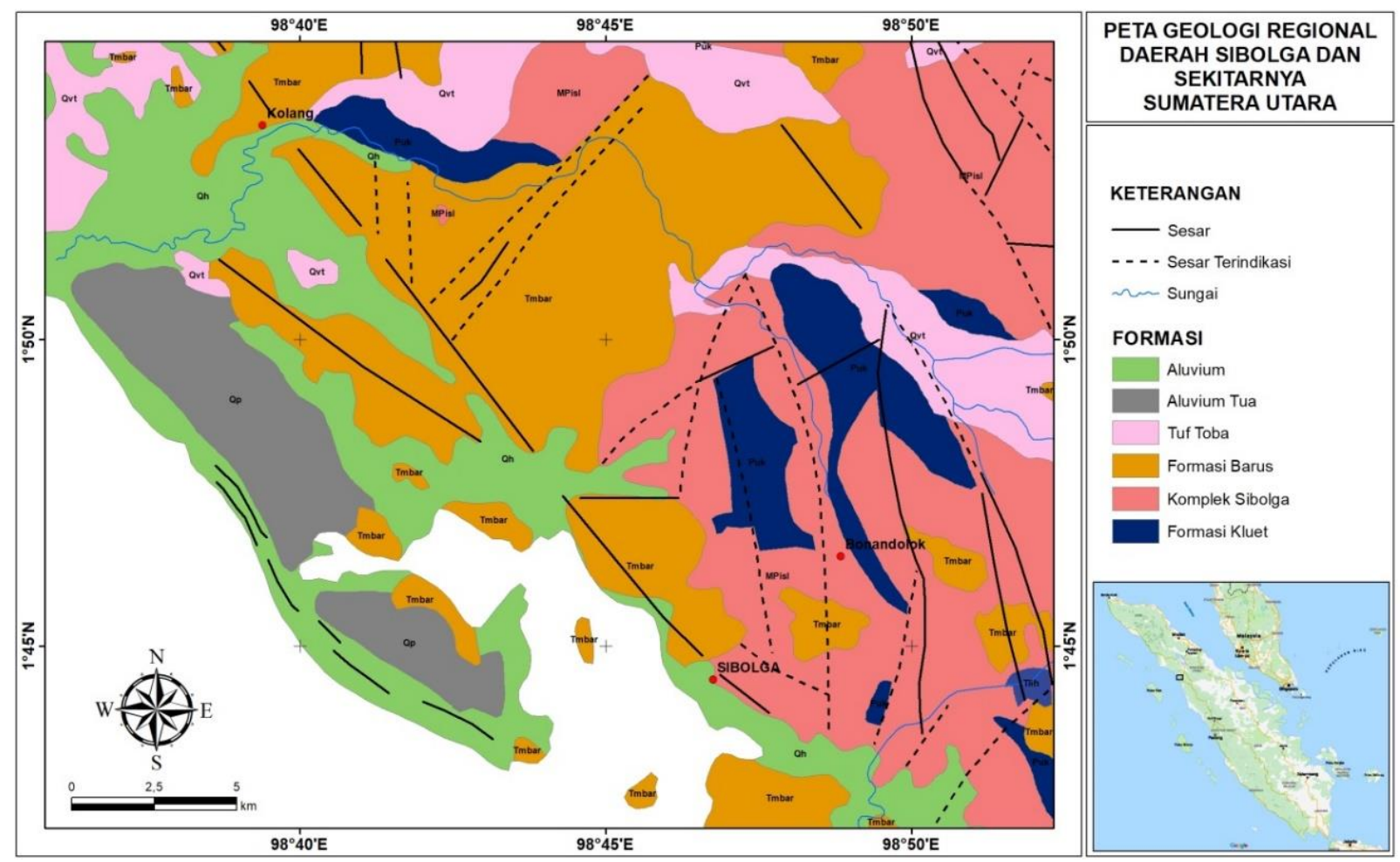

Gambar 4. Peta Geologi Regional Daerah Sibolga dan Sekitarnya, Sumatra Utara (modifikasi dari [7]).

Daerah Sibolga merupakan cekungan muka busur (fore-arc basin) berumur Tersier [12]. Hasil penyelidikan geofisika menunjukkan bahwa granit sebagai alas cekungan berada pada kedalaman dangkal di sebelah timur, kemudian semakin dalam di bagian tengah dan barat daya daerah penelitian [13].

Berdasarkan penelitian terdahulu, pengendapan uranium yang terjadi di daerah Sibolga merupakan hasil pelapukan batuan granit Formasi Sibolga seperti halnya yang umum terjadi pada endapan tipe sedimenter di dunia [6], [14-16]. Proses pelapukan dapat melarutkan unsur-unsur radioaktif dalam batuan sehingga terbawa oleh fluida dan terendapkan di lapisan yang kaya oleh material organik [6] seperti pada endapan tipe batupasir di Texas, Amerika Serikat [14] dan di banyak tempat di Benua Australia [15]. Kontrol mineralisasi uranium pada batupasir antara lain berupa konsentrasi uranium terlarut dari batuan sumber dan kuantitas aliran fluida pada batuan yang dipengaruhi oleh permeabilitas, ketebalan, serta gradien hidrogeologi [15].

Pengendapan batuan pembawa uranium di Aloban terjadi pada lingkungan pengendapan kipas aluvial [13]. Anomali kadar uranium umum dijumpai secara merata pada litologi batupasir dan konglomerat. Mineral radioakif yang terbentuk antara lain uraninit, karnotit, dan kofinit [3, 6]. Ilustrasi pengendapan uranium di daerah Sibolga ditunjukkan pada Gambar 6. 


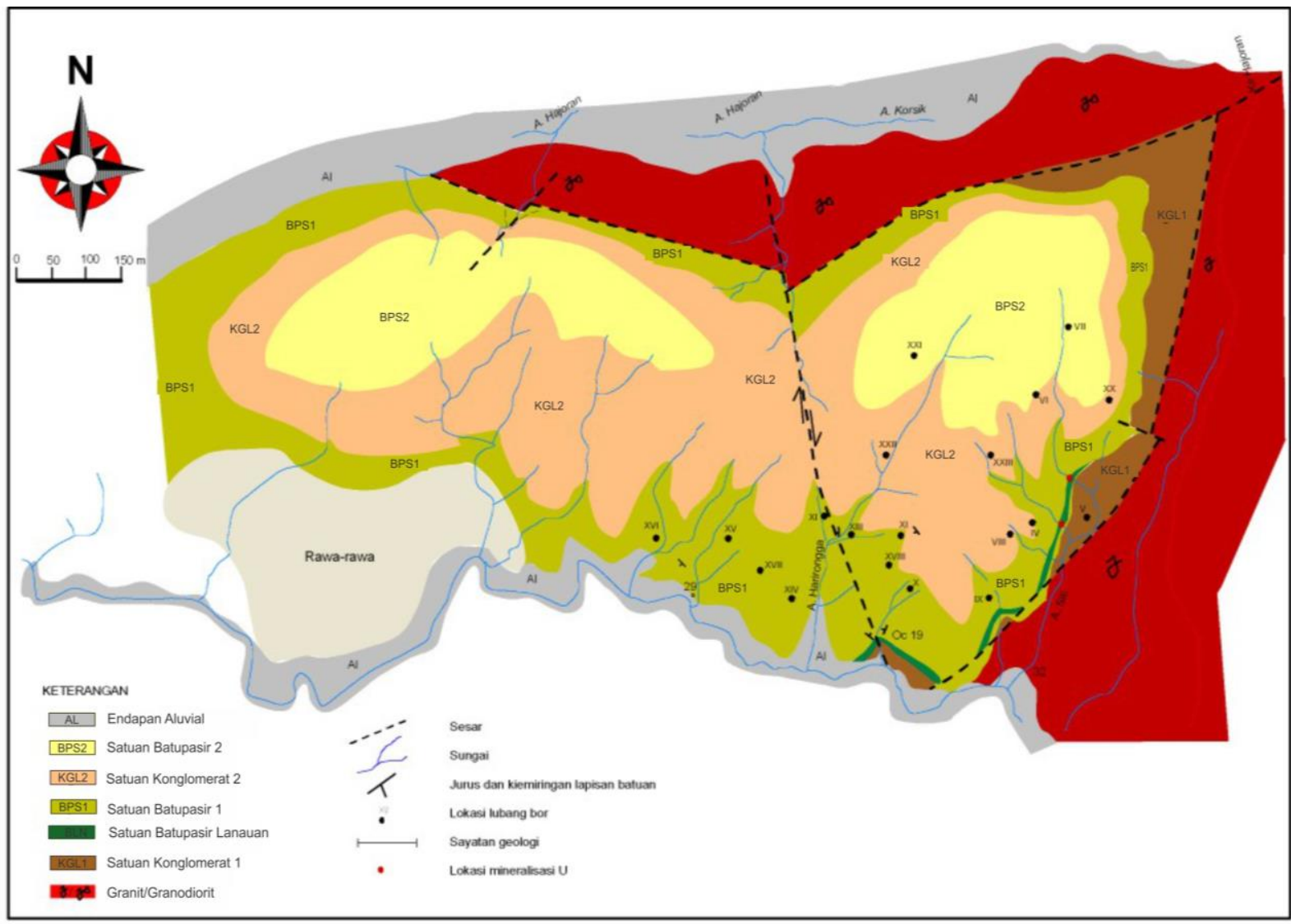

Gambar 5. Peta Geologi Sektor Aloban [6].

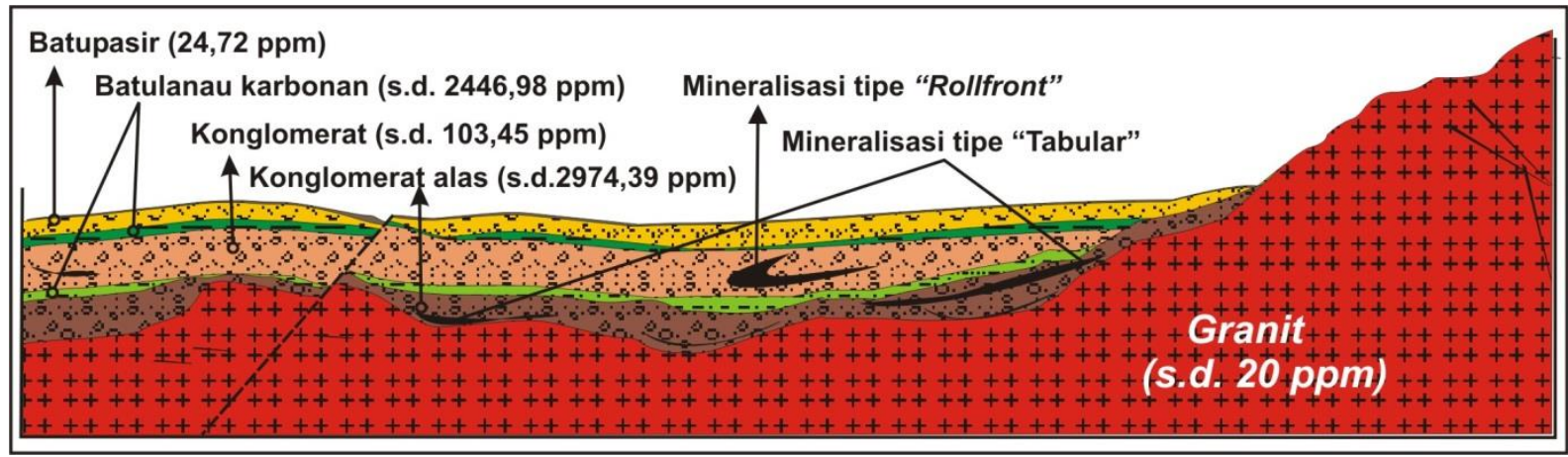

Gambar 6. Ilustrasi pengendapan uranium di daerah Sibolga [6].

\section{HASIL DAN PEMBAHASAN}

\section{Penampang Endapan}

Lima lintasan penampang telah dibuat melewati titik-titik bor yang tersebar di Sektor Aloban (Gambar 7). Lintasan penampang tersebut antara lain penampang A-A', B-B', C-C', D-D', dan E-E'.
Berdasarkan penampang tersebut (dicontohkan penampang A-A' dan C-C' pada Gambar 8 dan 9), mineralisasi uranium dijumpai pada Satuan KGL1, BPS1, KGL2, dan BPS2. Ketebalan rata-rata mineralisasi uranium pada masing-masing satuan ditunjukkan pada Tabel 1. 


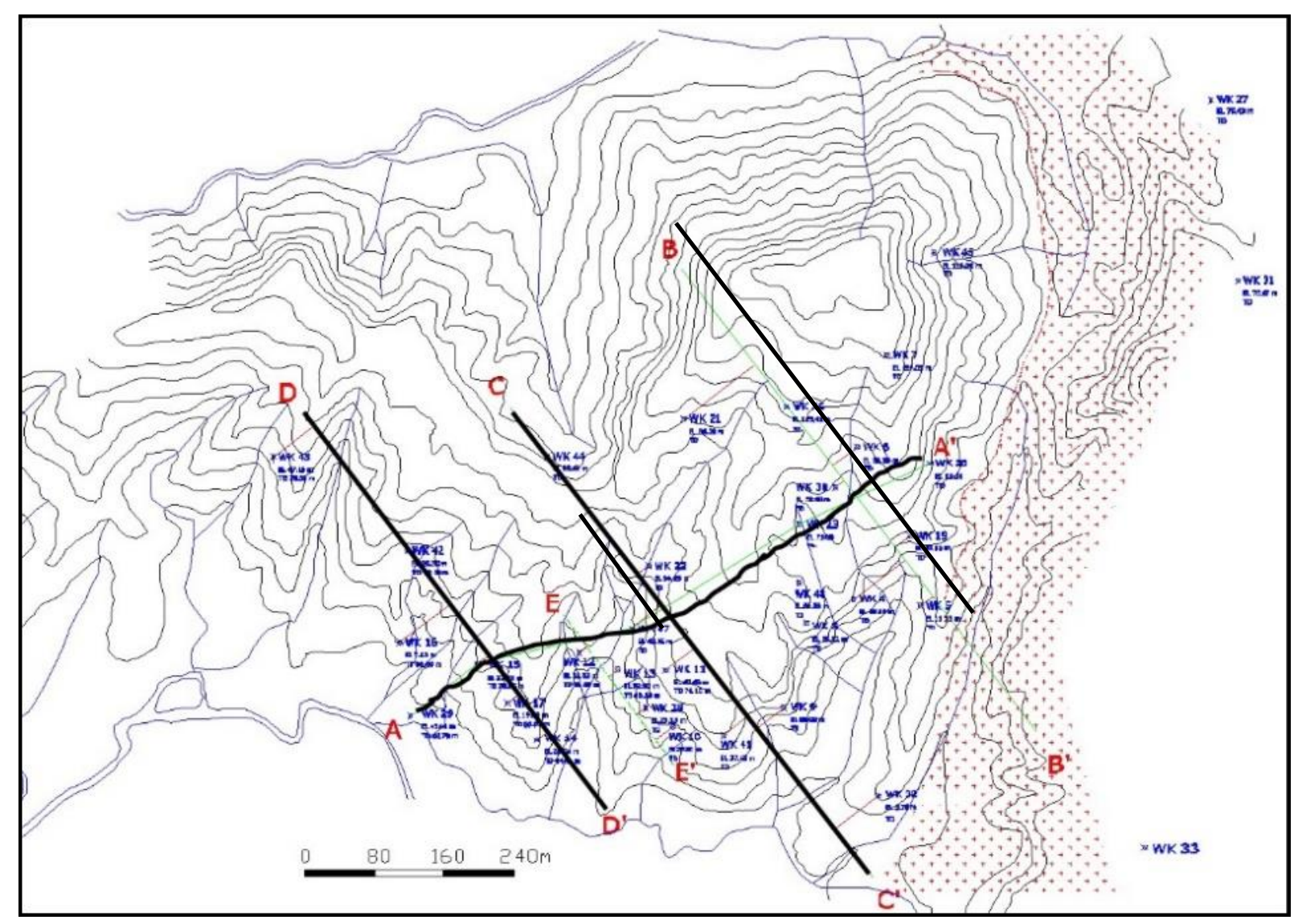

Gambar 7. Titik bor Sektor Aloban dan lintasan penampang geologi [6].

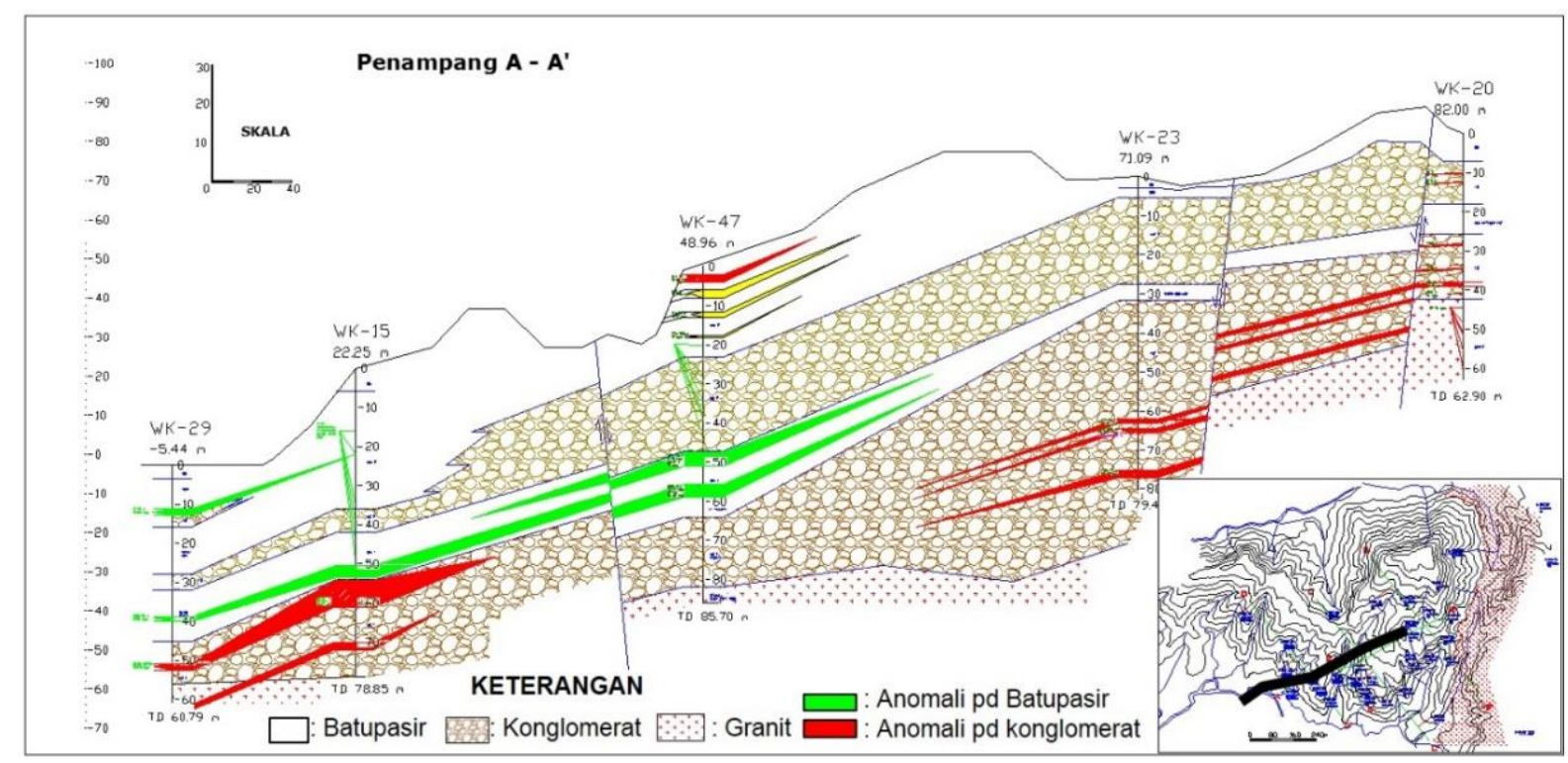

Gambar 8. Penampang geologi A-A’ [6]. 


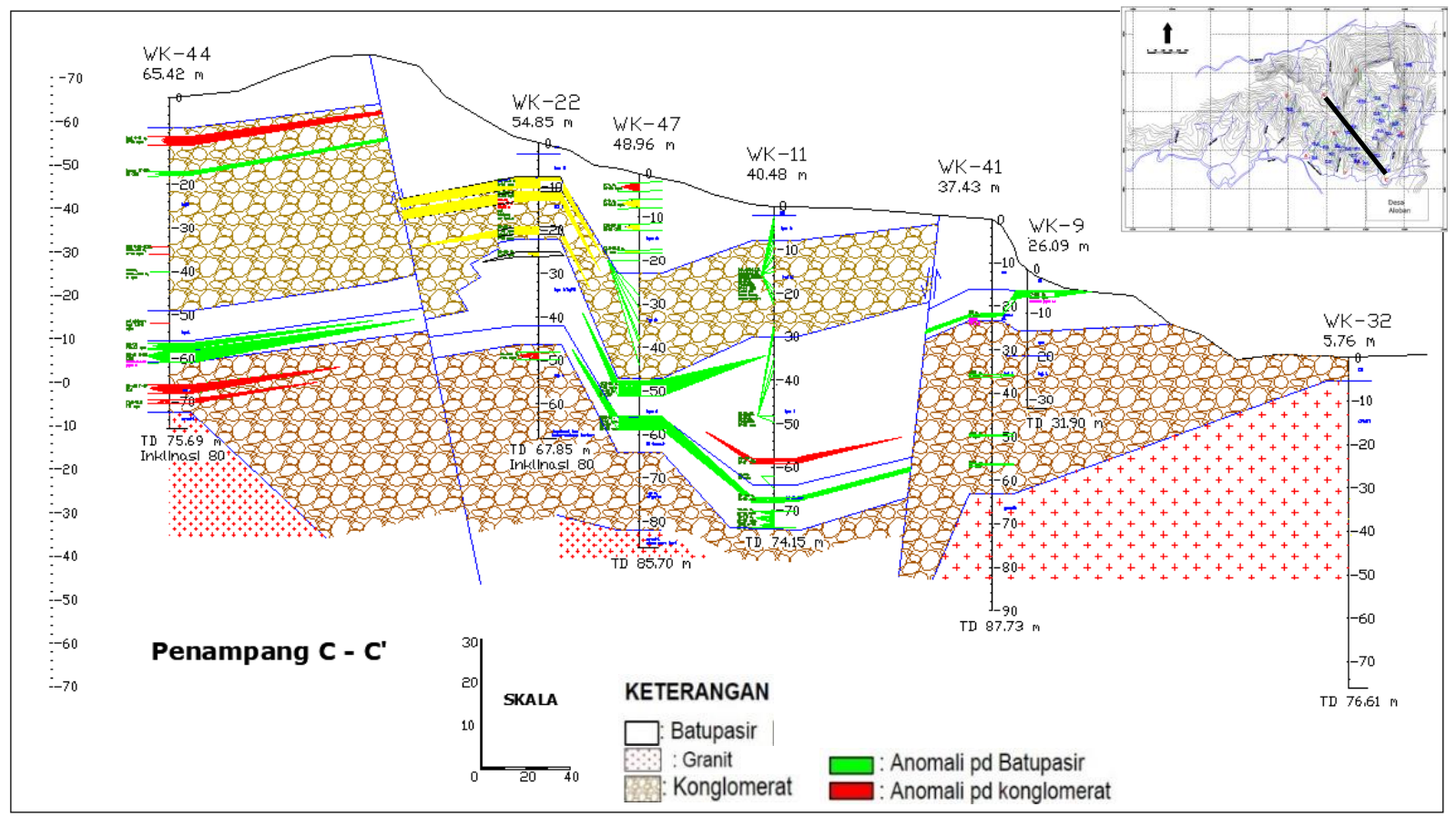

Gambar 9. Penampang geologi C-C' [6].

Tabel 1. Tebal rata-rata mineralisasi di Sektor Aloban.

\begin{tabular}{cc}
\hline Satuan & $\begin{array}{c}\text { Rerata Tebal Mineralisasi } \\
(\mathbf{m})\end{array}$ \\
\hline KGL1 & 2,6 \\
BPS1 & 2,5 \\
KGL2 & 1,0 \\
BPS2 & 0,5 \\
\hline
\end{tabular}

Hasil korelasi antarpenampang menunjukkan luas sebaran anomali uranium yang bervariasi di setiap satuan batuan (Gambar 10). Sebaran anomali pada Satuan KGL1 secara umum berarah barat-timur dengan luas mencapai $210.000 \mathrm{~m}^{2}$. Pada Satuan BPS1 dan KGL2, sebaran anomali berarah timurlaut-baratdaya dengan luas masing-masing $130.000 \mathrm{~m}^{2}$ dan $72.000 \mathrm{~m}^{2}$ sedangkan pada satuan paling muda, yaitu BPS2, sebaran anomali berarah barat-timur dengan luas sebaran $11.000 \mathrm{~m}^{2}$. Pada penelitian ini, perhitungan dilakukan pada Satuan KGL1 dan BPS1 karena sebaran anomali yang luas dan cukup tebal pada satuan tersebut.

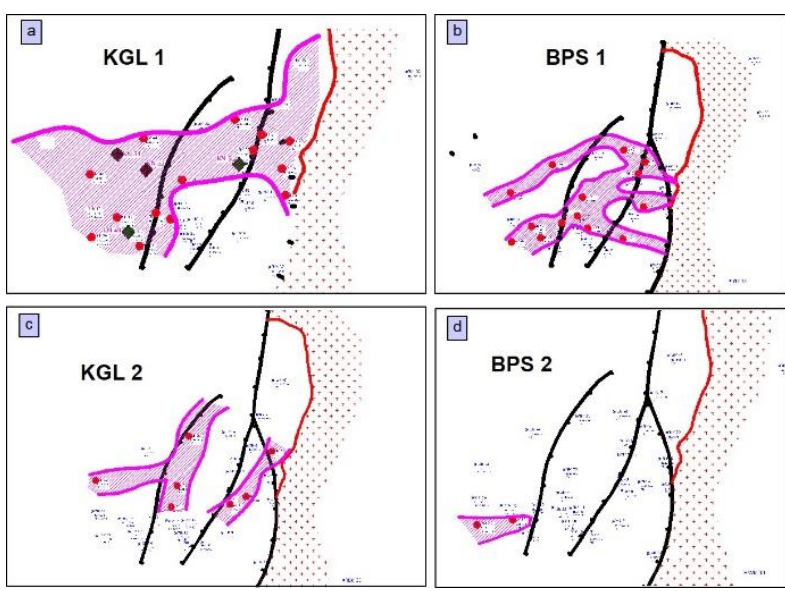

Gambar 10. Sebaran anomali pada satuan batuan di Sektor Aloban [6].

\section{Rerata Kadar}

Kadar uranium diketahui dari nilai radiometri hasil pengukuran logging geofisika. Logging geofisika dengan alat GMT 3T dan ST 22 telah dilakukan di Sektor Aloban, namun belum ada faktor konversi atau $k$-factor dari satuan radiometri count per second (cps) ke persen (\%) $\mathrm{U}_{3} \mathrm{O}_{8}$. Hubungan antara cacah yang terbaca dalam alat logging dengan kadar (ppm) uranium hasil analisis geokimia batuan dapat dicari dengan metode 
geostatistik [13]. Pendekatan geostatistik dilakukan dengan membuat scatter plot dari data yang ada. Scatter plot (Gambar 11) dibuat dengan bantuan perangkat lunak SGeMS sehingga diperoleh persamaan garis linier dan hubungan antara data logging dan data geokimia yang dinyatakan dalam koefisien korelasi.

Pengolahan scatter plot secara geostatistik untuk mendapatkan hubungan antara rerata kadar dari data geofisika seperti yang diterapkan pada penelitian ini pernah dilakukan oleh peneliti lain. Pada penelitian tersebut, metode geostatistik dinilai efektif untuk mendapatkan data rerata kadar [17].

Persamaan umum dari garis linier di notasikan sebagai $\mathrm{y}=\mathrm{ax}+\mathrm{b}$. Oleh karena itu dari data scatter plot (Gambar 11) dapat dibuat persamaan: dengan variabel $\mathrm{x}$ adalah jumlah cacahan radiometri dalam cps. Seperti yang terlihat pada Gambar 11, koefisien korelasi yang dihasilkan dari scatter plot data radiometri dengan data geokimia adalah 0,5 sehingga antara nilai cacahan radiometri dengan data geokimia diinterpretasikan cukup memiliki korelasi. Namun demikian, jumlah data yang digunakan sebagai dasar penentuan korelasi terbilang sedikit sehingga menurunkan tingkat kepercayaan.

Informasi nilai cacahan radiometri ratarata pada Satuan KGL1 dan Satuan BPS1 dapat diperoleh dari data penampang geologi sehingga nilai kadar rata-rata uranium pada satuan batuan tersebut juga dapat ditentukan. Nilai cacahan radiometri dan hasil perhitungan kadar pada Satuan KGL1 dan Satuan BPS1 dapat dilihat pada Tabel 2.

$$
\text { Kadar }=8,1 x+3,9
$$

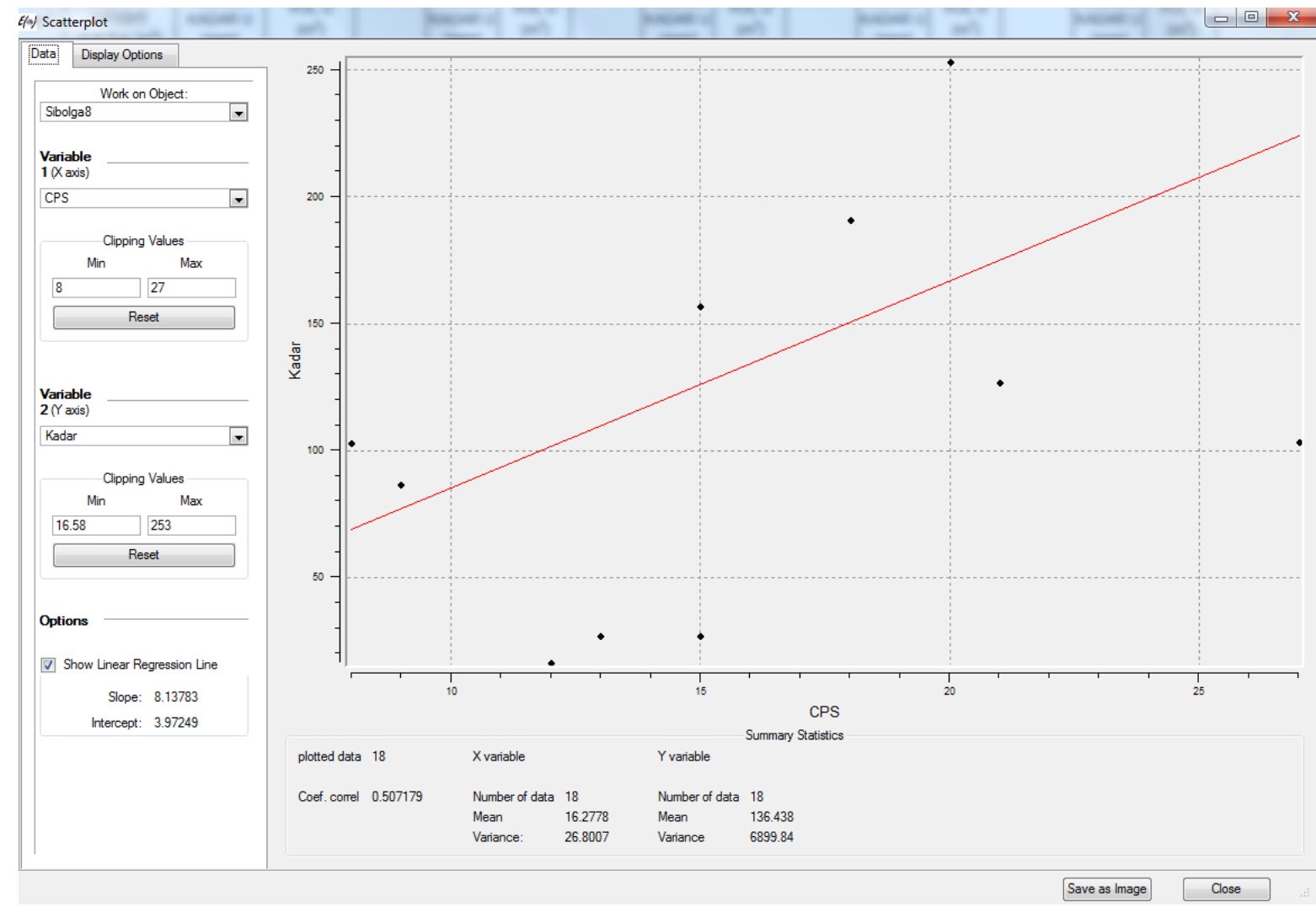

Gambar 11. Scatter Plot data logging dengan geokimia. 
Tabel 2. Nilai cps dalam logging dan hasil penghitungan kadarnya

\begin{tabular}{ccc}
\hline $\begin{array}{c}\text { Satuan } \\
\text { Batuan }\end{array}$ & $\begin{array}{c}\text { Cacahan Radiometri } \\
\text { (cps) }\end{array}$ & $\begin{array}{c}\text { Kadar } \\
\text { (ppm) }\end{array}$ \\
\hline KGL1 & 20,88095 & 173,03 \\
BPS1 & 19,46207 & 161,54 \\
\hline
\end{tabular}

\section{Estimasi Sumber Daya}

Setelah tebal, luas, serta kadar rata-rata mineralisasi didapatkan maka estimasi sumber daya uranium dilakukan pada Satuan KGL1 dan Satuan BPS1. Perhitungan dan parameter estimasi dapat dilihat pada Tabel 3.
Hasil perhitungan menunjukkan sumber daya uranium pada Satuan KGL1 adalah 265 ton dan pada Satuan BPS1 adalah 150 ton sehingga total sumber dayanya adalah 415 ton uranium. Meskipun perhitungan sudah dilengkapi dengan data bor, tetapi sedikitnya data cacahan radioaktif yang dijadikan dasar dalam konversi berpengaruh terhadap berkurangnya tingkat keyakinan. Oleh karena itu sumber daya yang dihasilkan dari estimasi ini dikategorikan sebagai sumber daya tereka [18].

Tabel 3. Estimasi sumber daya uranium Sektor Aloban.

\begin{tabular}{ccccccc}
\hline Satuan & $\begin{array}{c}\text { Area } \\
\left(\mathbf{m}^{\mathbf{2}}\right)\end{array}$ & $\begin{array}{c}\text { Tebal } \\
\text { Bijih }(\mathbf{m})\end{array}$ & $\begin{array}{c}\text { Volume Bijih } \\
\left(\mathbf{m}^{\mathbf{3}}\right)\end{array}$ & $\begin{array}{c}\text { Tonase Bijih } \\
(\text { ton) }\end{array}$ & $\begin{array}{c}\text { Rerata Kadar } \\
(\mathbf{p p m})\end{array}$ & $\begin{array}{c}\text { Sumber Daya U } \\
(\text { ton) }\end{array}$ \\
\hline KGL1 & 210000 & 2,6 & 546.000 & 1.528 .800 & 173,03 & 265 \\
BPS1 & 130000 & 2,5 & 325.000 & 926.250 & 161,54 & 150 \\
\hline
\end{tabular}

Keterangan: berat jenis 2,8 ton $/ \mathrm{m}^{3}$ )

\section{KESIMPULAN}

Sumber daya uranium di Sektor Aloban adalah 415 ton uranium dengan kategori sumber daya tereka. Tingkat keyakinan sumber daya ini masih dapat ditingkatkan dengan pemodelan tiga dimensi dari endapan serta penambahan data untuk menarik korelasi antara data cacahan radiometri dengan data geokimia.

\section{DAFTAR PUSTAKA}

[1] PTBGN BATAN, "Laporan Prospeksi Pendahuluan Daerah Sibolga," Jakarta, 1978.

[2] M. Seredkin, A. Zabolotsky, and G. Jeffress, "In Situ Recovery, an Alternative to Conventional Methods of Mining: Exploration, Resource Estimation, Environmental Issues, Project Evaluation and Economics," Ore Geol. Rev., vol. 79, pp. 500-514, 2016.

[3] M. Masdja, S. Sastrowihardjo, and P. Tampubolon, "Uranium Mineralisation in Sibolga Formation at Aloban, North Sumatera," Proceeding Semin. Uranium Explor. Geol. Extr., pp. 123-144, 1989.

[4] International Atomic Energy Agency, IAEA Tecdoc Series: Geological Classification of
Uranium Deposits and Description of Selected Examples. Vienna: International Atomic Energy Agency, 2018.

[5] S. Thakur, B. Chudasama, and A. Porwal, "Global grade and tonnage modelling of uranium deposits," in Quantitative and Spatial Evaluations of Undiscovered Uranium Resources, Vienna: International Atomic Energy Agency, 2018, pp. 218-262.

[6] I. G. Sukadana and H. Syaeful, "Evaluasi Sistem Pengendapan Uranium pada Batuan Sedimen Formasi Sibolga , Tapanuli Tengah," Eksplorium, vol. 37, no. 2, pp. 125-138, 2016.

[7] J. A. Aspde, W. Kartawa, D. T. Aldiss, A. Djunuddin, D. Diatma, M. C. G. Clarke, R. Whandoyo, and H. Harahap, "Peta Geologi Lembar Padang Sidempuan dan Sibolga, Sumatera," Bandung, 1992.

[8] E. Usman, "The Geochemical Characteristic of Major Element of Granitoid of Natuna , Singkep , Bangka and Sibolga Karakteristik Geokimia Unsur Utama Granitoid Natuna , Singkep , Bangka dan Sibolga," Bull. Mar. Geol., vol. 30, no. 1, pp. 45-54, 2015.

[9] C. S. Hutchinson, "Tectonic evolution of Southeast Asia," Bull. Geol. Soc. Malaysia, vol. 60, no. December, pp. 1-18, 2014.

[10] I. Setiawan, R. Takahashi, and A. Imai, "Petrochemistry of Granitoids in Sibolga and its Surrounding Areas, North Sumatra, Indonesia," 
Resour. Geol., vol. 67, no. 3, pp. 254-278, 2017.

[11] E. L. Advokaat, M. L. M. Bongers, A. Rudyawan, M. K. BouDagher-Fadel, C. G. Langereis, and D. J. J. van Hinsbergen, "Early Cretaceous Origin of the Woyla Arc (Sumatra, Indonesia) on the Australian Plate," Earth Planet. Sci. Lett., vol. 498, pp. 348-361, 2018.

[12] R. Sukhyar, A. D. Wirakusumah, D. Sukarna, N. Suwarna, Surono, E. B. Santoso, N. Buyung, and T. O. Simandjuntak, "Sedimentary Basin Map of Indonesia Based on Gravity and Geological Data," Bandung, 2009.

[13] A. G. Muhammad, H. Syaeful, and P. Widito, "Survey Geolistrik Tahanan Jenis di Daerah Aloban dan Sekitarnya, Sibolga, Sumatera Utara," Eksplorium, vol. 30, no. 152, pp. 45-61, 2009.

[14] S. M. Hall, M. J. Mihalasky, K. R. Tureck, J. M. Hammarstrom, and M. T. Hannon, "Genetic and Grade and Tonnage Models for Sandstone-Hosted Roll-Type Uranium Deposits, Texas Coastal Plain, USA," Ore Geol. Rev., vol. 80, pp. 716-
$753,2017$.

[15] S. Jaireth, I. C. Roach, E. Bastrakov, and S. Liu, "Basin-Related Uranium Mineral Systems in Australia: A Review of Critical Features," Ore Geol. Rev., vol. 76, pp. 360-394, 2016.

[16] N. J. Cook, R. Bluck, C. Brown, C. L. Ciobanu, and U. Domnick, "Petrography and Geochemistry of Granitoids from the Samphire Pluton, South Australia: Implications for Uranium Mineralisation in Overlying Sediments," Lithos, vol. 300-301, pp. 1-19, 2017.

[17] O. Asghari, S. Sheikhmohammadi, M. Abedi, and G. A. Norouzi, "Multivariate Geostatistics Based on a Model of Geo-Electrical Properties for Copper Grade Estimation: a Case Study in Seridune, Iran," Bull. di Geofis. Teor. ed Appl., vol. 57, no. March, pp. 43-58, 2016.

[18] Badan Standarisasi Nasional, Standar Nasional Indonesia 4726:2011 Pedoman Pelaporan, Sumber Daya, dan Cadangan Mineral. Jakarta, 2011. 